\title{
Pembekalan Ilmu Perhitungan Digital Berbasis Stand Alone dan Cloud Melalui Excel dan Spreadsheet
}

\author{
Rizky Pradana $^{1)}$, Riri Irawati' ${ }^{2)}$, Agnes Aryasanti $^{3)}$, Dwi Achadiani $^{4)}$, Hendri Irawan $^{5)}$ \\ Fakultas Teknologi Informasi Universitas Budi Luhur ${ }^{1,2,3,4,5)}$ \\ Jalan Ciledug Raya Jakarta Selatan, DKI Jakarta Indonesia \\ Email: rizky.pradana@budiluhur.ac.id
}

\begin{abstract}
ABSTRAK
Pandemi yang berkepanjangan saat ini mengharuskan setiap individu untuk melakukan social distancing dan phsycal distancing. Hal ini membuat perubahan pola belajar dan bekerja. Dalam rangka mengatasi hal tersebut dan menyiapkan tenaga kerja kedepannya, maka diperlukan suatu pembiasaan pola belajar dan bekerja melalui perangkat yang dimiliki dari rumah atau tempat tinggal. Untuk meningkatkan performa dari proses belajar maka diperlukan suatu mekanisme pembelajaran tambahan tentang pemanfaatan teknologi, khususnya di bidang perhitungan digital. Dalam rangka mengatasi masalah tersebut pada pihak mitra, maka tim membuat suatu solusi yaitu berupa pembekalan dengan pola pelatihan menggunakan Microsoft Excel yang menjadi dasar suatu pola perhitungan umum yang biasa digunakan baik di dunia pendidikan maupun di dunia kerja dan juga pemanfaatan Google Spreadsheet. Metode yang dipakai dalam pembekalan ini adalah dengan learning by doing, yaitu metode dimana setiap siswa yang mengikutinya akan terjun langsung untuk praktek dengan mengikuti instruksi dari instruktur pelatihan dari tim PKM. Berdasarkan pada pelatihan yang diberikan, didapat hasil rata-rata post test sebesar 76,6 dari rentang 0-100, atau peningkatan sebesar 23,28\% dari Pre Test ke Post Test.
\end{abstract}

Kata kunci: Excel, Perhitungan, Teknologi, Digital, Spreadsheet

\begin{abstract}
The current prolonged pandemic requires every individual to do social distancing and physical distancing. This made a difference study and work patterns. In order to overcome this and prepare workforce in the future, it requires an habituation of learning patterns and work through devices you own from your home or residence. To improve the performance of the learning process, an additional learning mechanism is needed on the use of technology, especially in the field of digital calculations. In order to solve this problem on the partner's side, the team made a solution, namely in the form of provisioning with a training pattern using Microsoft Excel which is the basis for a general calculation pattern commonly used both in the world of education and in the world of work and also the use of Google Spreadsheets. The method used in this debriefing is learning by doing, which is a method where every student who follows it will go directly to practice by following instructions from the training instructor from the PKM team. Based on the training provided, the average post test result is 76.6 from the 0-100 range, or increasment 23,28\% at from Pre Test to Post test
\end{abstract}

Keywords: Excel, calculation, technology, digital, spreadsheet 


\section{Pendahuluan}

Pada semester ini, dunia sedang dihebohkan oleh munculnya virus corona jenis baru yaitu covid-19 yang awal mula penyebarannya berasal dari Wuhan Cina. Hal ini memiliki dampak yang sangat besar di seluruh belahan dunia, karena virus ini menyebar begitu pesat.

Dampak dari pandemi ini mengakibatkan beberapa kebijakan yang diberikan oleh pemerintah Republik Indonesia, salah satunya adalah penerapan Pembatasan Sosial Berskala Besar (PSBB). Penerapan tersebut, sesuai dengan Permenkes pasal 13 nomor 9 tahun 2020. Berdasarkan pada isi Permenkes tersebut, maka fokus dari Pengabdian Kepada Masyarakat kali ini adalah bagaimana cara memberikan sesuatu yang berguna untuk melakukan pencegahan (penularan) atau penanganan (solusi) dari masalah yang didampaki oleh hal tersebut dengan cara memberikan pembekalan secara daring yang nantinya dapat dimanfaatkan oleh peserta dalam menjalankan kegiatan secara social distancing. Dimana poin yang menjadi konsentrasi pemecahan masalah diantaranya yaitu peliburan sekolah dan tempat kerja, pembatasan kegiatan di tempat atau fasilitas umum dan pembatasan kegiatan lainnya. Hal ini tentunya membuat kegiatan pembelajaran untuk mitra PKM menjadi tidak normal, sehingga memerlukan suatu solusi pembelajaran yang tidak melanggar peraturan yang tengah diberlakukan di masa pandemi Covid-19 ini.

Selain itu, masalah yang menjadi konsentrasi di saat ini adalah menghadapi jaman milenial yang dimana segala hal serba cepat, serba instan, serba praktis dan tidak dibatasi oleh jarak dan waktu. Hal ini tentunya membutuhkan suatu metode pembelajaran untuk bekal para siswa sesuai dengan perkembangan jamannya guna meningkatkan daya saing nantinya di dunia kerja. Salah satu permasalahan adalah beralih dari model pembelajaran luring ke daring.

Permasalahan yang dimiliki oleh mitra, antara lain terkait dengan kuantitas dan kualitas pembelajaran yang ada. Pada kuantitas terkait dengan data yang tertera pada laman situs Kemendikbud adalah tidak adanya guru yang khusus mengajarkan mata pelajaran tentang teknologi komputer dimana guru yang ada saat ini adalah guru Matematika, Ekonomi, Bahasa Inggris, Pendidikan Kewarganegaraan, Bahasa Indonesia, Sejarah, Geografi, Agama dan Sosiologi. Selanjutnya permasalahan kualitas yang dimiliki antara lain fasilitas ruang belajar yang terbatas, sebab ruang kelas hanya memiliki meja dan bangku, adaptasi di era milenial saat ini dengan kategori serba cepat, serba praktis dan tak terbatas oleh jarak dan waktu yang dinilai sulit, mimimnya pembekalan pengetahuan di bidang teknologi saat ini sesuai dengan perkembangan jaman, tidak adanya pembekalan teknologi di bidang umum secara khusus, yaitu penggunaan Microsoft Office, terutama Microsoft Excel untuk perhitungan, dimana pembekalan ini berguna untuk siswa dalam memperoleh pekerjaan yang memerlukan digital measurenment di ranah administrasi

Solusi yang ditawarkan guna mengatasi permasalahan yang dihadapi oleh mitra antara lain memberian pembelajaran dari tim Pengabdian Kepada Masyarakat yang memiliki kompetensi di bidang teknologi, terutama teknologi informasi, memfasilitasi dengan mengadakan pembekalan pembelajaran secara daring melalui perangkat smartphone dan komputer yang dimiliki oleh masing-masing peserta dengan sistem learning by doing dari studi kasus yang diberikan. Pembekalan yang diberikan adalah pelatihan perhitungan digital dengan memanfaatkan Microsoft Excel dan dalam rangka adaptasi terhadap era milenial saat ini, pelatihan yang diberikan dikolaborasikan dengan cloud computing, dan memanfaatkan media Google Apps dalam menunjang kolaborasi yang cepat, praktis, tak terbatas oleh waktu dan jarak sesuai dengan tuntutan milenial.

Target luaran yang diharapkan dalam pelaksanaan PKM ini antara lain Peningkatan keahlian dan pengetahuan peserta pelatihan dapam PKM ini. Kemudian pemberian fasilitas yang dapat dimanfaatkan secara daring oleh para peserta pelatihan dalam forum diskusi sehingga memudahkan dalam proses pembelajaran. Selain itu juga video tutorial pembelajaran dalam pelatihan yang 
diberikan. Terakhir adalah modul pendamping kegiatan pelatihan dalam upaya peningkatan pengetahuan.

\section{Tinjauan Pustaka}

Pengolahan data pada komputer dapat menggunakan Microsoft Excel untuk data-data yang menggunakan angka (Azizah, 2018). Diantara pemanfaatannya, pengolahan data bisa berupa pengolahan data untuk nilai rapot (Riani, 2015). Penggunaan Microsoft Excel juga dapat dikolaborasikan dengan aplikasi lain, seperti Microsoft Power Point untuk keperluan presentasi (Juanita, 2020). Peningkatan kinerja pada pelatihan Microsoft Excel dapat digunakan untuk memaksimalkan potensi (Niati, 2019). Pemanfaatan ini dapat juga untuk kegiatan administrasi (Julaeha, 2019).

\section{Metodologi Penelitian}

Metode pelaksanaan dalam merealisasi solusi yang diciptakan terhadap permasalahan yang ada terbagi ke dalam tiga tahapan. Ketiga tahapan itu antara lain Pre Training, Present Training dan terakhir Post Training. Pada Pre Training, yang dilakukan adalah survei terhadap mitra, untuk melihat situasi di sana. Pada survei tersebut, dilakukan juga wawancara terhadap kebutuhan dari mitra tentang jenis pembekalan yang diperlukan guna menunjang keperluan dari para peserta PKM nantinya. Setelah mendapatkan apa yang dibutuhkan oleh mitra, langkah selanjutnya adalah studi literatur dan pustaka untuk pembuatan materi pembekalan yang berupa pelatihan. Setelah studi literatur dan pustaka selesai langkah selanjutnya adalah membuat Forum Grup Discussion (FGD) dengan mitra untuk pembuatan surat permintaan dari mitra untuk mengadapak pembekalan berupa pelatihan secara praktek di lab. Terakhir, setelah surat permintaan diterima, langkah selanjutnya adalah pembuatan materi pembelajaran.

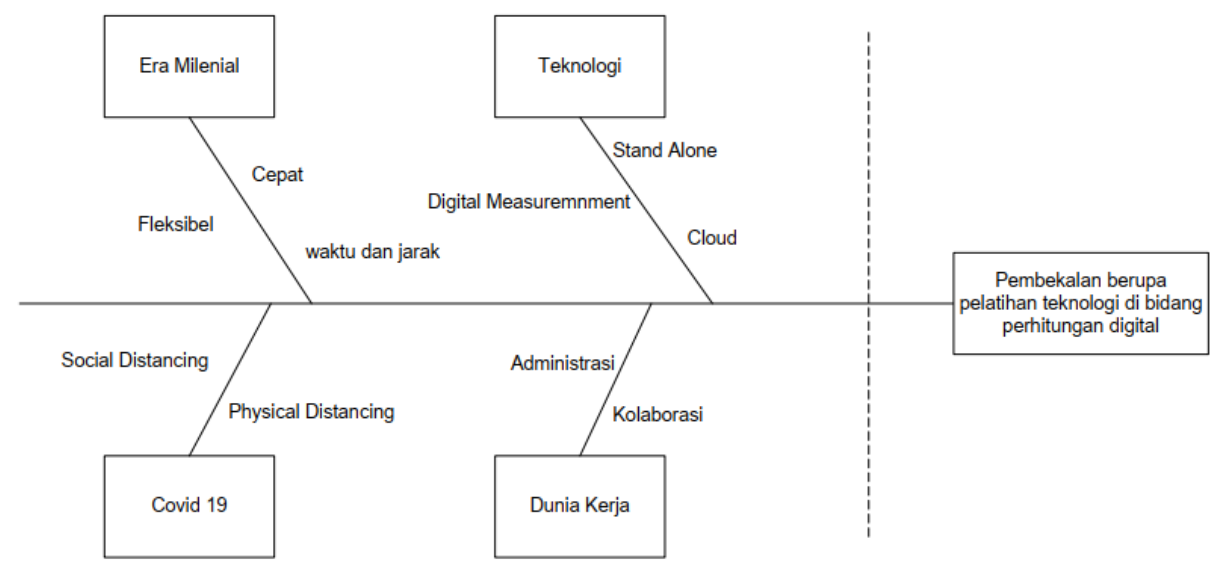

Gambar 1. FGD dengan Mitra

Selanjutnya adalah Present Training tahapan yang diberikan terbagi ke dalam tiga sekuensial tahapan, yaitu pre test, pelatihan dan terakhir post test. Pada pre test, peserta akan diberikan soal terkait dengan materi yang akan di berikan, yaitu materi tentang Microsoft Excel. Pre test ini digunakan untuk mengukur seberapa dalam pengetahuan peserta terhadap pembekalan yang akan di berikan. Setelah pre test langkah selanjutnya adalah pemberian pembekalan berupa pelatihan menggunakan aplikasi Microsoft Excel dan Google Spreadsheet. Pada tahap ini, pelatihan diberikan dalam tiga proses. Proses yang pertama yaitu ceramah tentang pentingnya pengetahuan di bidang perhitungan digital untuk suatu pekerjaan beserta contoh-contoh real dalam dunia kerja. Selanjutnya yang kedua adalah pemberian pelatihan secara learning by doing tentunya dengan model tutorial yang diinstruksikan oleh instruktur yaitu anggota tim Pengabdian Kepada 
Masyarakat (PKM) dan didampingi oleh anggota dari tim PKM yang lain. Pada tahap ini selain pemberian tutorial, juga diselingi dengan diskusi dan tanya jawab antara peserta dan tim PKM. Terakhir dalam present training adalah tahap post test. Pada tahap ini, peserta diwajibkan menjawab soal dan menyelesaikan studi kasus yang diberikan berkaitan dengan pelatihan yang telah dilaksanakan. Tahap yang paling akhir adalah post training, yaitu tahap di mana peserta diminta untuk mengisi kuisioner yang berkaitan dengan fasilitas fisik dan fasilitas pembekalan yang berupa pelatihan, kedua hal ini akan dijadikan bahan untuk koreksi diri guna meningkatkan kualitas pelayanan terhadap kegiatan pengabdian kepada masyarakat yang dilakukan. Setelah kuisioner diselesaikan, yang terakhir adalah sesi foto bersama antara seluruh peserta dan tim PKM.

\section{Hasil dan Pembahasan}

Pada pelaksanaan PKM kali ini, jumlah peserta yang mengikuti kegiatan ini berjumlah 16 peserta dari 20 peserta. Berdasarkan pada kuisioner yang diberikan, terdapat data bahwa peserta yang mengikuti pelatihan Microsoft Excel ini memiliki status marital lajang dengan persentase $80 \%$ dan sisanya sudah menikah. Hasil survey ini dimaksud untuk mendapatkan nilai dari tolak ukur konsentrasi selama mengikuti pelatihan. Selanjutnya pada gender, pelatihan kali ini didominasi oleh perempuan yaitu sebesar 73,3\% dan laki-laki sebanyak $26,7 \%$. Selain itu peserta dalam kegiatan ini memiliki range usia yang cukup jauh, yaitu mulai dari 16 tahun sampai dengan 28 tahun. Melalui sistem survey yang diperoleh, untuk peserta dengan usia 16 tahun terdapat 1 orang, usia 17 tahun sejumlah 1 orang, usia 18 tahun 2 orang, usia 19 tahun 3 orang, usia 20 sebanyak 2 orang, usia 22 tahun sebanyak 2 orang, usia 22, 24, 25 dan 28 masing-masing sejumlah 1 orang. Dari total keseluruhan peserta yang mengisi survey ini ada 15 orang. Terakhir data peserta yang dihimpun dalam pelaksanaan PKM ini adalah data tentang pekerjaan yang dilakukan oleh masing-masing peserta disamping mengikuti kejar paket yang diikuti baik kejar paket $\mathrm{A}$, paket $\mathrm{B}$ maupun paket $\mathrm{C}$ yang ada di Mitra. Berdasarkan survey yang diperoleh, terdapat enam jenis pekerjaan yang dimiliki, yaitu asisten rumah tangga, grab kitchen, 13 karyawan swasta, dan wiraswasta. Selain itu ada yang masih belum memiliki pekerjaan.

\subsection{Langkah Pelaksanaan}

Langkah yang ditempuh dari awal hingga akhir pelaksanaan PKM antara lain pembentukan grup di aplikasi WhatsApp dengan nama "Pelatihan Excel UBL 2021". Grup ini bertujuan untuk koordinasi antara instruktur dan peserta pelatihan. Dimana anggotanya terdiri dari peserta dan perwakilan instruktur. Selanjutnya setelah grup terbentuk, dilakukan koordinasi untuk kegiatan. Kegiatan ini dibagi ke dalam tiga tahapan. Tahapan tersebut yaitu tahap pre test, dimana peserta diberikan soal melalui Google Form yang disusun secara random dan hanya dapat mengisi satu kali untuk setiap pesertanya. Sebelum link Google Form ini dibagikan, terlebih dahulu dilakukan pembukaan dan absensi melalui Google Meet yang dilaksanakan pada dengan link https://meet.google.com/zfv-doan-avq. Di link tersebut para instruktur yaitu Hendri Irawan, S.Kom, M.T.I, Rizky Pradana, M.Kom dan instruktur lainnya melakukan ramah tamah dengan para peserta dan koordinator dari pihak Mitra yaitu Claudia Annis Laurent, Amd. Berikut adalah foto yang diambil pada saat pembukaan pelatihan 


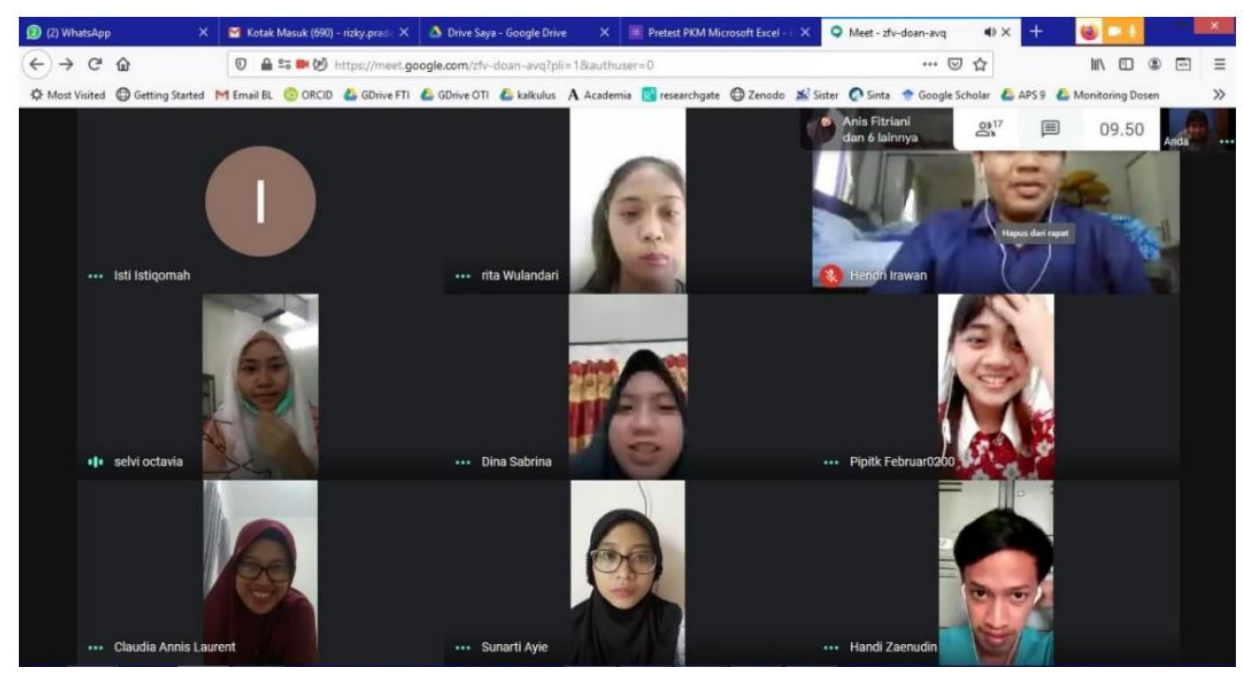

Gambar 2. Pertemuan Daring Pelatihan

Pada saat pembukaan acara, jumlah peserta yang hadir adalah sebanyak 14 peserta, sisa peserta yang tidak hadir dikarenakan sedang ada pekerjaan yang sedang dilakukan. Selain itu terdapat juga 1 koordinator dari pihak Mitra, yaitu Claudia Annis Laurent dan para instruktur dari tim PKM. Setelah melakukan absensi, langkah selanjutnya adalah memberikan link Google Form untuk para peserta melakukan pre test. Link pre test yang diberikan adalah https://forms.gle/jTR6814x33Q8NA7y5. Pelaksanaan pre test adalah 60 menit dan selama melakukan pre test masing-masing peserta dibatasi hanya dapat mengisi satu kali.

Berdasarkan hasil pre test yang dilaksanakan, diperoleh nilai rata-rata peserta adalah 62,19 dari 100 dengan rentang angka mulai dari 40 sampai 85. Perolehan nilai terbanyak dari pre test yang dilakukan adalah 65 dengan jumlah peserta sebanyak 4 peserta. Kemudian disusul oleh perolehan 40, 60 dan 75, dengan pemuatan grafik masih ke arah kiri (rendah). Berikut adalah hasil pre test yang dilakukan dalam bentuk grafik:

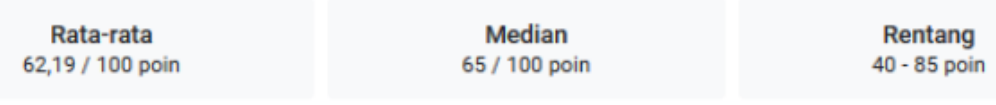

Distribusi poin total

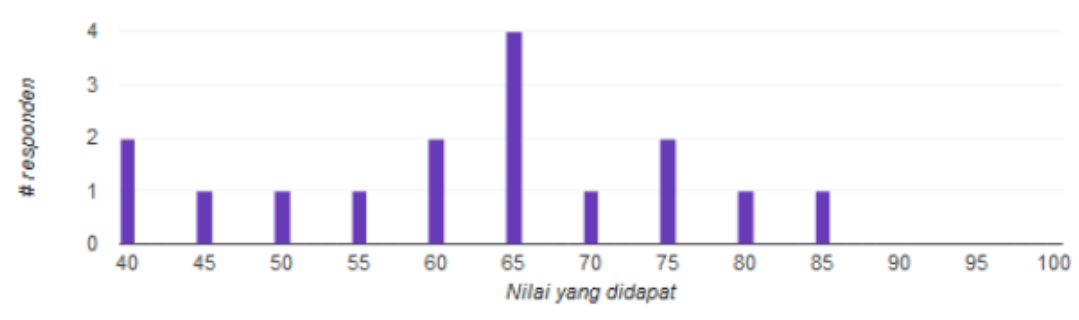

Gambar 3. Nilai Hasil Pre Test

Selanjutnya setelah pemberian pre test dilanjutkan dengan pemberian materi dan tutorial. Pemberian materi dan tutorial ini diberikan satu hari setelah pelaksanaan pre test. Hal ini diberikan satu hari setelah pre test karena dari tim PKM harus menganalisa terlebih dahulu pada bagian mana sajakah peserta kurang memahami isi dari pelatihan yang akan di berikan. Materi yang diberikan berupa file dengan format pdf yang terdiri dari tahap awal membuka aplikasi sampai dengan pemanfaatan formula untuk perhitungan di dalam Microsoft Excel. Pembagian materi ini dibagikan melalui grup daring yang sudah dibentuk. Selain materi berupa file pdf, tim PKM juga memberikan 
video tutorial melalui link youtube yang direkam oleh tim PKM dengan link https://youtu.be/BhSbaFLSzmY.

Pada pelaksanaannya, tim PKM memberikan keleluasaan bagi peserta untuk mempelajari dan melakukan praktek dimanapun selama 6 hari. Selain itu dari tim PKM juga memberikan kesempatan bertanya kepada tim PKM melalui grup daring yang sudah dibuat selama rentang waktu tersebut. Akhir dari pelaksanaan pelatihan ini adalah diadakannya post test. Pelaksanaan post test ini diikuti oleh 15 peserta dari 20 peserta. Hasil perolehan nilai yang di dapat antara lain adalah nilai rata-rata dari para peserta yang ikut adalah 76,67 dari 100, kemudian rentang nilai yang diperoleh mulai dari 45 sampai dengan 90. Berikut adalah gambar grafik detil dari pelaksanaan post test :

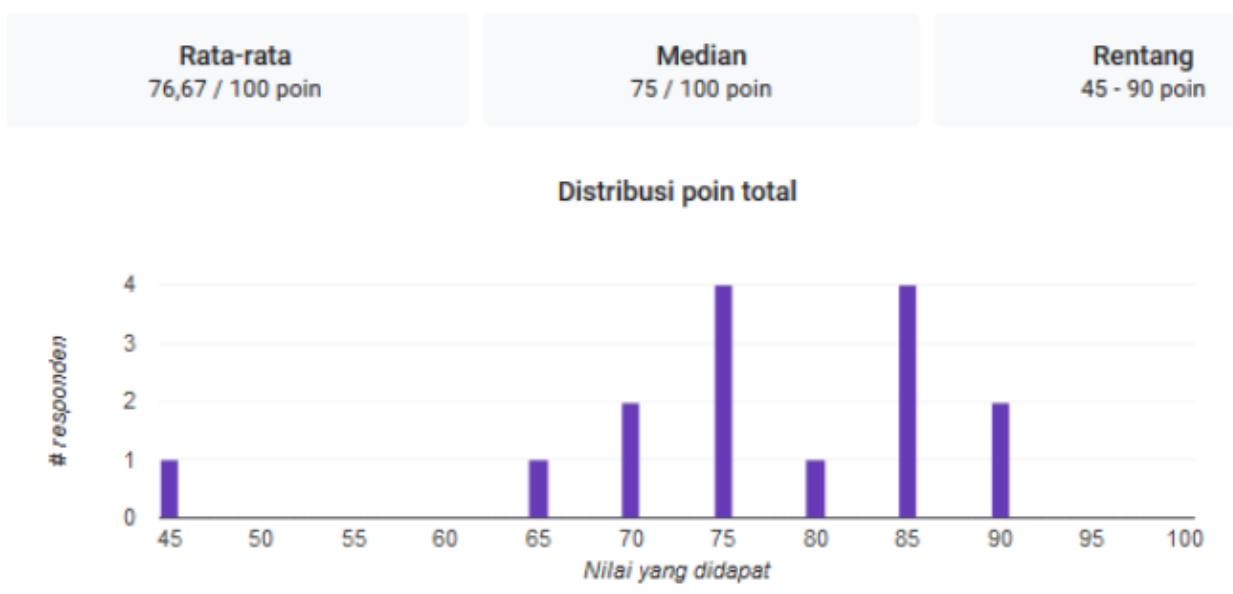

Gambar 4. Hasil Post Test

Selain perolehan nilai post test, tidak lupa, dilakukan juga penilaian terhadap tim pelaksana PKM dari para peserta yang dilakukan melalui survei. Survei tersebut terdiri dari tiga konsentrasi penilaian, yaitu penilaian terhadap instruktur, penilaian terhadap materi yang diberikan dan terakhir penilaian terhadap fasilitas yang digunakan selama PKM berlangsung. Berdasarkan pada hasil penilaian terhadap instruktur, diperoleh hasil rata-rata dari jawaban yang diberikan responden yaitu 10,43 dari 15 dengan menyatakan bahwa instruktur sangat kompeten. Selanjutnya pada hasil survei bagian kedua, yaitu penilaian terhadap fasilitas, yang terdiri dari bahan ajar dan ruang diskusi serta pertemuan online yang dilakukan, diperoleh nilai rata-rata terbesar adalah sangat layak, dengan rata-rata perolehan 10,5 dari 15 responden. Terakhir dari survei yang diberikan ke peserta pelatihan adalah penilaian tentang seberapa mendukungnya materi yang diberikan terhadap post test dan peningkatan kemampuan peserta pelatihan. Berdasarkan survei yang disebarkan secara daring, diperoleh hasil rata-rata terbesar menunjukkan materi yang diberikan sangat mendukung terhadap point tersebut. Hasil yang diperoleh adalah 10,5 dari 15 .

\subsection{Luaran Yang Dicapai}

Berdasarkan pada hasil yang diperoleh selama pelatihan berlangsung, terdapat beberapa luaran yang dicapai, antara lain: Berdasarkan pada hasil pre test dan post test yang dilaksanakan terdapat peningkatan kemampuan rata-rata peserta sebesar 14,48. Selain itu peningkatan juga terlihat pada nilai minimum dan maksimum dari para peserta pelatihan sebesar 5 poin, yaitu dari 40 ke 45 dan dari 85 ke 90, serta perolehan nilai peserta terbanyak mendapatkan nilai dari yang semula 65 menjadi 75 dan 85 dengan jumlah peserta sebanyak 4 dan tidak ada lagi 22 peserta yang mendapatkan nilai 50 sampai 60. Lebih jelasnya dapat dilihat pada grafik berikut: 


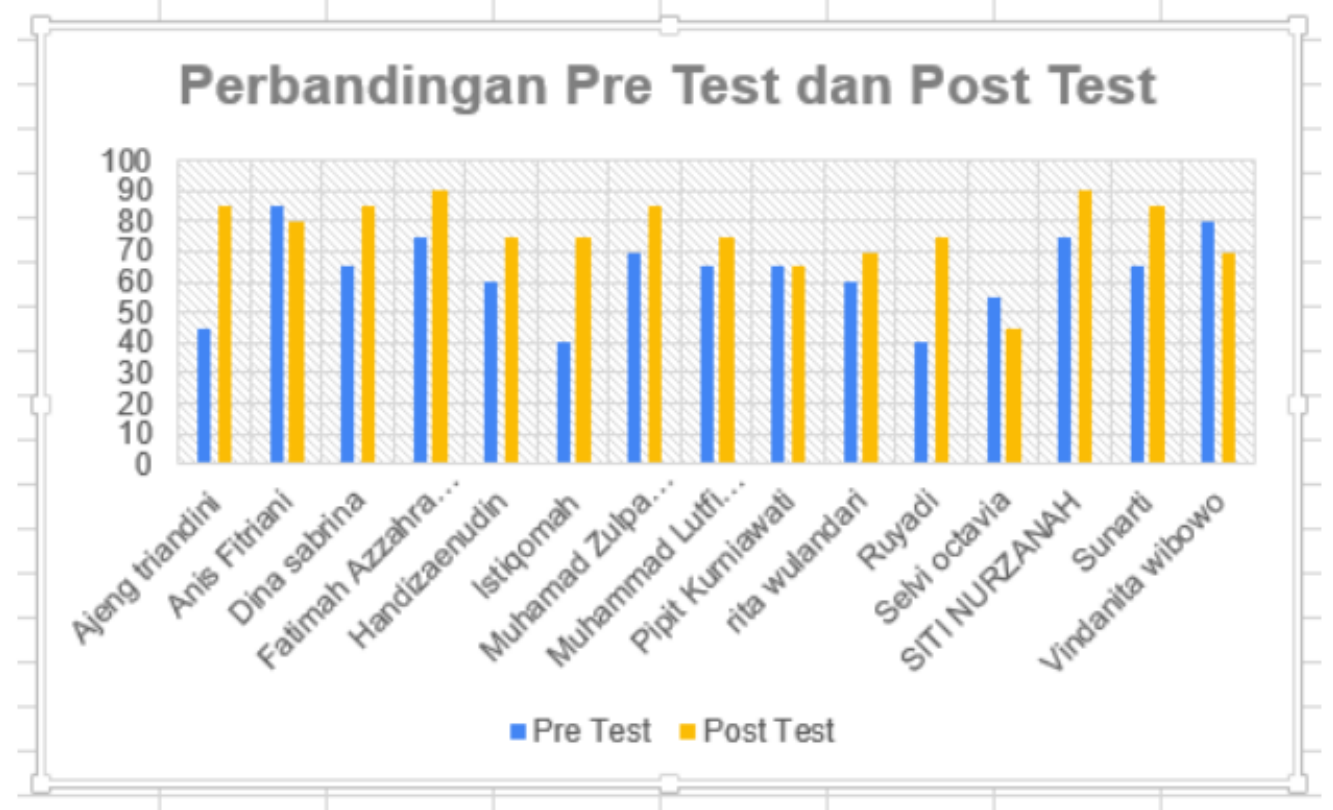

Gambar 5. Perbandingan Nilai Pre Test dan Post Test

Selanjutnya yang kedua adalah berdasarkan hasil survei terhadap penilaian instruktur, diperoleh capaian sebesar $69 \%$ menilai bahwa instruktur pelatihan dalam PKM ini sangat kompeten, untuk lebih jelasnya dapat di lihat pada grafik berikut ini:

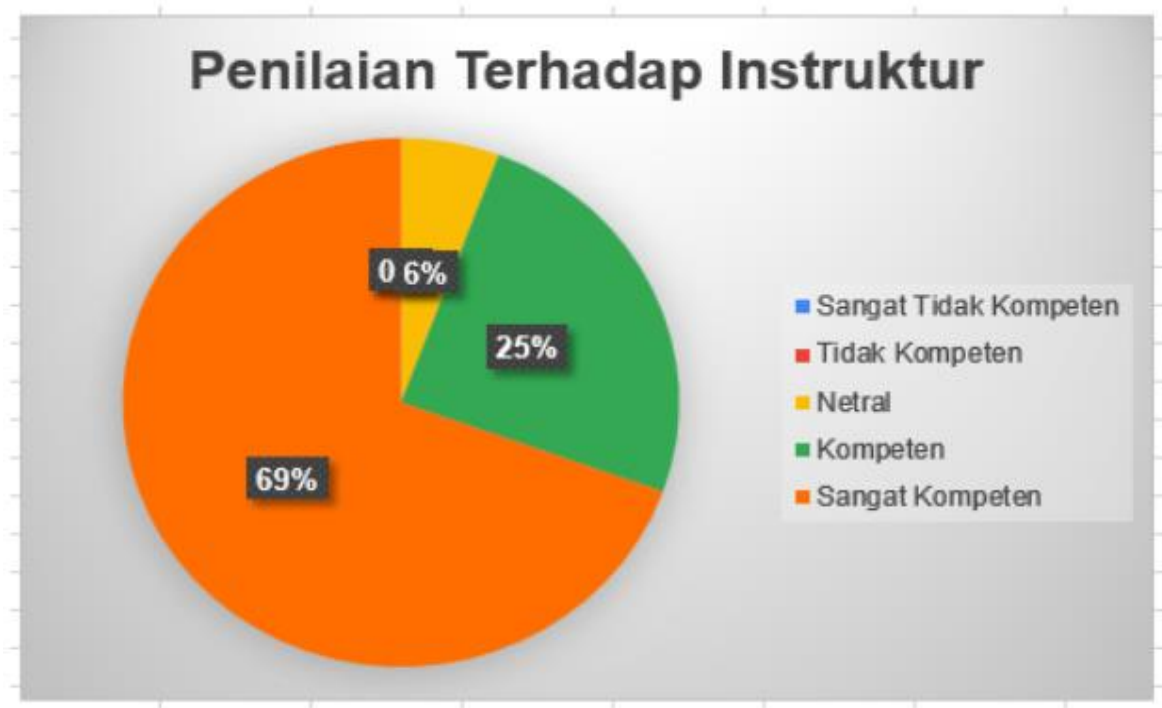

Gambar 6. Persentase Penilaian Instruktur

Hasil survei terhadap materi yang diberikan, baik berupa video maupun file yang berupa pdf didapat capaian $70 \%$ sangat mendukung. Untuk lebih jelasnya dapat dilihat pada grafik berikut ini: 


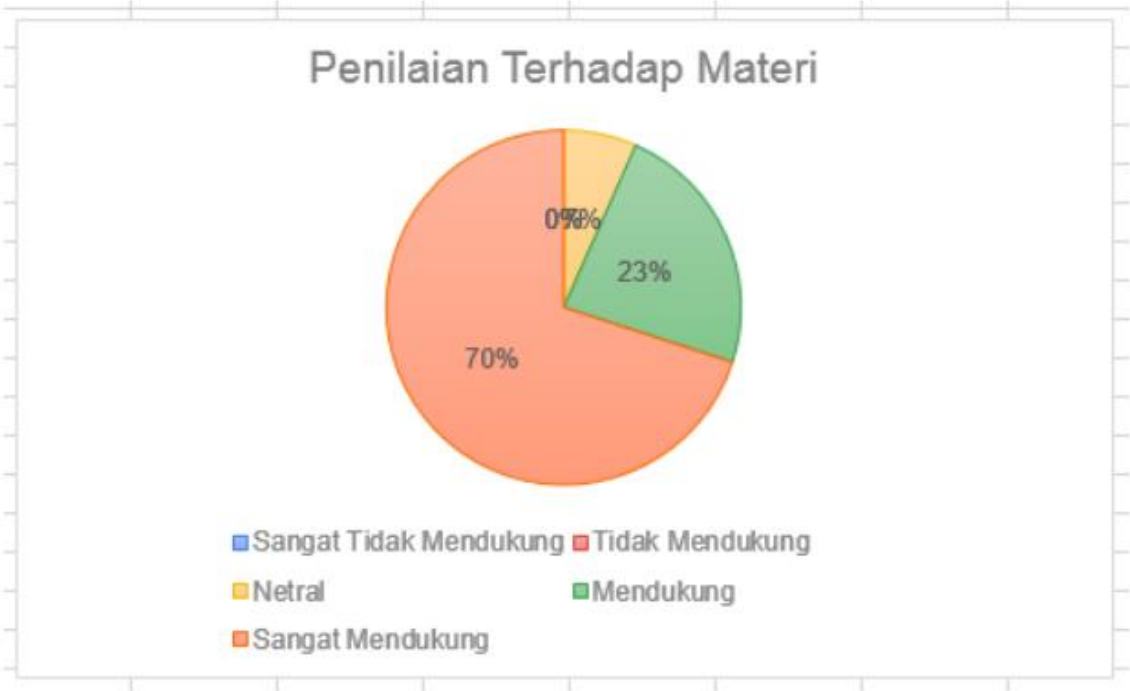

Gambar 7. Persentase Penilaian Materi

Terakhir capaian terhadap fasilitas yang diberikan dinilai sangat layak sebanyak $70 \%$. Berikut grafik yang menunjukkannya:

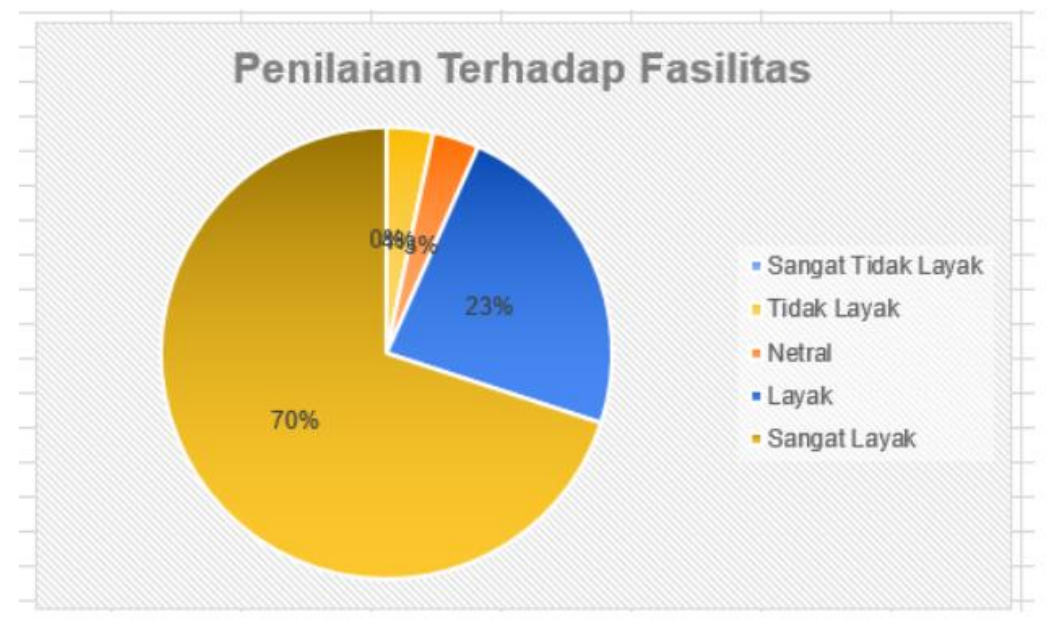

Gambar 8. Persentase Penilaian Fasilitas

\section{Kesimpulan}

Berdasarkan pada permasalahan yang ada, kemudian setelah dilaksanakannya pelatihan, maka dapat disimpulkan bahwa :

a. Kurangnya fasilitas sarana dan prasarana di mitra dan pandemi Covid-19 yang melanda Indonesia dapat diatasi dengan fasilitas daring yang diberikan, yaitu melalui aplikasi grup WhatsApp, pertemuan dengan menggunakan fasilitas Google Meet, pemberian materi melalui video Youtube dan penyebaran file modul pelatihan melalui aplikasi daring, serta pelaksanaan pre test dan post test yang memanfaatkan Google Form.

b. Adaptasi terhadap perkembangan jaman yang diajarkan dalam PKM ini kepada peserta adalah dengan secara langsung mempraktekkan segala hal melalui media daring, dengan selogan dimanapun dan kapanpun tetap dapat belajar, karena semua hal dilakukan secara daring, mulai dari mengumpulkan peserta sampai dengan pengisian angket.

c. Bekal teknologi yang secara umum diberikan yaitu pemanfaatan media online untuk tetap bisa menimba ilmu dan berkumpul secara daring, yaitu pemanfaatan Google, WhatsApp dan Youtube. 
d. Bekal teknologi secara khusus yang diberikan adalah pemberian bekal pengetahuan terhadap penggunaan dan pemanfaatan aplikasi Microsoft Excel yang dilakukan secara daring maupun luring.

e. Berdasarkan perolehan nilai dari pre test dan post test yang diperoleh peserta pelatihan ini mengalami peningkatan sebesar $23,28 \%$.

f. Penilaian terhadap tim PKM oleh peserta pada penilaian terhadap instruktur memperoleh 94\% baik, kemudian penilaian terhadap materi yang diberikan mendapat $95 \%$ baik dan penilaian terhadap fasilitas yang diberikan 25 mendapatkan nilai 95\% baik. Sehingga dari nilai hasil keseluruhan survei didapat nilai persentase rata-rata baik adalah 94,67\% baik.

\section{Daftar Pustaka}

Azizah Sormin, Masdelima, Nur Sahara, Lisna Agustina. (2018). Pelatihan Pemanfaatan Perangkat Lunak (Microsoft Office Word, Excel, Power Point) Dalam Kinerja Pengolahan Data Di Pemerintahan Desa Bagi Kepala Desa Sekecamatan Batang Angkola. MARTABE : Jurnal Pengabdian Masyarakat Vol 1 No 2 Tahun 2018 Hal 78-82, p-ISSN: 2598-1218, eISSN: 2598-1226

Riani Putri, Asti. (2015). Optimalisasi Penggunaan Microsoft Excel Untuk Pengolahan Nilai Raport Di Sman 1 Ngunut Tulungagung. J-ADIMAS (Jurnal Pengabdian kepada Masyarakat) Volume 3, Nomor 1, Juli 2015: 1 - 5

Juanita, Safitri, Putri Hayati, Dolly Virgian Shaka Yudha Sakti. (2020). Peningkatan Keterampilan Menyajikan Presentasi Menarik Dan Interaktif Bagi Guru Pkbm Negeri 27 Petukangan Dengan Pelatihan Microsoft Power Point. SEBATIK 2621-069X

Niati, Asih, Anitiyo Soelistiyono, Teguh Ariefiantoro. (2019). Pengembangan Kemampuan Sumber Daya Manusia melalui Pelatihan Komputer Microsoft Office Excel untuk Meningkatkan Kinerja Perangkat Desa Mranggen. EDIMAS: Jurnal Pengabdian kepada Masyarakat, 10(1), 105-110 ISSN 2087- 3565 (Print) dan ISSN 2528-5041 (Online) Available Online at http://journal.upgris.ac.id/index.php/e-dimas

Julaeha, Siti, Somawati. (2019). Sosialisasi Pengoperasian Microsoft Excel Untuk Administrasi Data Matematis Pada Karang Taruna. Jurnal PKM: Pengabdian kepada Masyarakat, Vol. 02 No. 03, September-Desember 2019, p-ISSN 2614-574X, e-ISSN 26154749, hal. 280-286 